\title{
Assessment of knowledge and practice of menstrual hygiene among the female nursing students in a selected private nursing college in Dhaka City
}

\author{
Niru Shamsun Nahar ${ }^{1,2}$, Ratna Khatun ${ }^{1}$, Khondoker Mahmuda Akter Halim², \\ Sharmin Islam ${ }^{1}$, Faisal Muhammad ${ }^{3 *}$
}

\begin{abstract}
${ }^{1}$ Department of Adult Medical and Surgical Nursing, Grameen Caledonian College of Nursing, Mirpur-2, Dhaka, Bangladesh

${ }^{2}$ Department of Nutrition, Grameen Caledonian College of Nursing, Mirpur-2, Dhaka, Bangladesh

${ }^{3}$ Department of Public Health, Faculty of Allied Health Sciences, Daffodil International University, Dhaka, Bangladesh
\end{abstract}

Received: 15 March 2019

Accepted: 09 April 2019

*Correspondence:

Dr. Faisal Muhammad,

E-mail: fokkanya@yahoo.com

Copyright: () the author(s), publisher and licensee Medip Academy. This is an open-access article distributed under the terms of the Creative Commons Attribution Non-Commercial License, which permits unrestricted non-commercial use, distribution, and reproduction in any medium, provided the original work is properly cited.

\begin{abstract}
Background: Adolescent females are often uninformed and inexperienced on most health-related issues including menstruation. The problems of menstrual hygiene are inadequately acknowledged and has not received any proper attention as well. This study was aimed to assess the level of knowledge and practice of menstrual hygiene among the female nursing students in Bangladesh.

Methods: A total of 106 female nursing students were selected from Grameen Caledonian College of nursing using purposive sampling technique. A descriptive cross-sectional type of study was used. Data were collected directly using self-administered semi-structured questionnaire developed and was analysed using SPSS version 22.0.

Results: In this study more than six-tenths $(63.2 \%)$ of the respondents were 20 years and below and most of them (74.5\%) were unmarried. About $60.4 \%$ of them were currently running diploma in nursing and the rest $(38.6 \%)$ were B.Sc. nursing students. About $72.6 \%$ of the respondent's mothers had above HSC level of education and most of them $(61.3 \%)$ were from nuclear family. Little above half $(51.9 \%)$ of the respondents mentioned that menstruation is the uterine bleeding and the majority $(67.0 \%)$ of the respondents were surprised during their first menstruation. Most of the respondents source of information about menstruation before menarche was sister (95.3\%), followed by friend $(92.5 \%)$, mother $(67.9 \%)$ and the rest mentioned the teacher $(62.3 \%)$. About $76.5 \%$ of the respondents mentioned that their mode of disposal of absorbents was dustbin and most of them $(68.9 \%)$ used water and soap to clean their genital area after menstruation.

Conclusions: The study was concluded that more than half of the respondents had moderate level of knowledge and practice regarding the menstrual hygiene. Most of the $(67.0 \%)$ of the respondents were surprised during their first menstruation and close to eight-tenths (79.2\%) mentioned they had a regular usual menstrual cycle. There is need for more awareness regarding the information on good menstrual hygiene practices.
\end{abstract}

Keywords: Hygiene, Knowledge, Mesntruation, Nursing-Students, Practice

\section{INTRODUCTION}

Worldwide every year approximately about $10 \%$ of women are exposed to genital infections including urinary tract infections and bacterial vaginosis, and more than seven-tenths of women have a history of a genital infection. Pregnancy and poor hygienic status both Perineal and menstrual hygiene are the common risk 
factors for vaginal infections. ${ }^{1}$ The issue of menstrual hygiene is inadequately acknowledged and has not received proper attention. ${ }^{2}$ Good hygienic practices, such as use of sanitary pads and proper washing of the genital areas, are important during menstruation period. Women of reproductive age need access to clean and soft absorbent sanitary products which in the long run protect their health from various infections. ${ }^{3}$ A study described a knowledge of the menstrual process which is part of sex education is often clouded with secrecy in some cultures, and these are not often discussed in public, because the topics related to sexual development are, therefore, avoided from school and colleges curriculum. Therefore, such knowledge is passed mostly from mothers, sisters, aunts, and grandmothers to daughters. ${ }^{4}$ There is limited information regarding the menstrual hygiene among the Bangladeshi nurses. This study was aimed to assess the level of knowledge and practice of menstrual hygiene among the female nursing students in Bangladesh.

\section{METHODS}

A total of 106 female nursing students were selected from Grameen Caledonian College of nursing using purposive sampling technique. A descriptive cross-sectional type of study was conducted among the nursing students to identify their level of knowledge and practice regarding the menstrual hygiene. All the female nursing students who were currently studying in this college were included and male nursing students were excluded for participation.

An official request was made to the concern authority before staring the study in Grameen Caledonian Nursing College. Oral request were made to the students and the written informed consent was also taken. The study was approved by the Grameen Caledonian Nursing College, Dhaka Bangladesh.

\section{Statistical analysis}

All the data were collected directly using selfadministered semi-structured questionnaire developed by the researchers. A written and verbal informed consent was taken from the students and all were given clear instructions on how to fill the questionnaires. The collected data were checked for completeness and correctness. All the information collected were coded numerically and entered into the SPSS version 22.0 software program for analysis.

\section{RESULTS}

\section{Socio-demographic characteristics of the respondents}

Table 1 showed that more than six-tenths $(63.2 \%)$ of the respondents were 20 years and below and most of them $(74.5 \%)$ were unmarried. About $81.1 \%$ of the respondents were Muslims and slightly above three-fifths $(60.4 \%)$ were currently running diploma in nursing and the rest $(38.6 \%)$ were B.Sc. nursing students. Little above eight-tenths $(80.2 \%)$ were from urban areas and most of their family monthly income was more than 15000 taka. About $72.6 \%$ of the respondent's mothers had above HSC level of education and most of them (61.3\%) were from nuclear family.

Table 1: Socio-demographic characteristics of the respondents $(n=106)$.

\begin{tabular}{|c|c|c|}
\hline Variables & Frequency & Percent \\
\hline \multicolumn{3}{|l|}{ Age (years) } \\
\hline$\leq 20$ & 67 & 63.2 \\
\hline$\geq 21$ & 39 & 36.8 \\
\hline \multicolumn{3}{|l|}{ Marital status } \\
\hline Married & 27 & 25.5 \\
\hline Unmarried & 79 & 74.5 \\
\hline \multicolumn{3}{|l|}{ Religion } \\
\hline Muslim & 86 & 81.1 \\
\hline Non-Muslim & 20 & 18.9 \\
\hline \multicolumn{3}{|c|}{ Educational background (Presently Studying) } \\
\hline Diploma in nursing & 64 & 60.4 \\
\hline B.Sc. in nursing & 42 & 39.6 \\
\hline \multicolumn{3}{|l|}{ Residence } \\
\hline Rural & 21 & 19.8 \\
\hline Urban & 85 & 80.2 \\
\hline \multicolumn{3}{|c|}{ Family monthly income (Taka) } \\
\hline$\leq 15000$ & 30 & 28.3 \\
\hline$>15000$ & 76 & 71.7 \\
\hline \multicolumn{3}{|c|}{ Mother's educational level } \\
\hline Up to HSC & 29 & 27.4 \\
\hline Above HSC & 77 & 72.6 \\
\hline \multicolumn{3}{|l|}{ Family type } \\
\hline Joint family & 29 & 27.4 \\
\hline Nuclear family & 65 & 61.3 \\
\hline Extended family & 12 & 11.3 \\
\hline
\end{tabular}

\section{Knowledge about menstrual hygiene}

Table 2 shows that little above half $(51.9 \%)$ of the respondents mentioned that menstruation is the uterine bleeding, $28.3 \%$ of them mentioned that is the bleeding from stomach and the rest $(19.8 \%)$ stated that menstruation is the white discharge. Regarding the causes of menstruation about $57.5 \%$ of the respondents mentioned that it occurs naturally, $23.6 \%$ mentioned that it is hormonal and $18.9 \%$ of them mentioned that it's physical. About $67.9 \%$ of the study participants mentioned that their menarche age was 11-13 years and the rest mentioned it was 14-16 years. The majority $(67.0 \%)$ of the respondents were surprised during their first menstruation, $54.7 \%$ of them mentioned that its normal for them and $44.3 \%$ were afraid during first menstruation. About $66 \%$ of the respondents mentioned that use of sanitary pad is the concept about menstrual hygiene and most of the respondents source of information about menstruation before menarche was sister $(95.3 \%)$, followed by friend $(92.5 \%)$, mother 
$(67.9 \%)$ and the rest mentioned the teacher $(62.3 \%)$. Close to eight-tenths (79.2\%) mentioned they had a regular usual menstrual cycle and the remaining $(20.8 \%)$ had irregular menstrual cycle. A half $(50 \%)$ of the respondents mentioned that they experienced inter menstrual interval for $25-28$ days and $40.6 \%$ of them mentioned that the duration for menstrual cycle during each period was 3-5 days.

Table 2: Knowledge about menstrual hygiene ( $n=106)$.

\begin{tabular}{|c|c|c|}
\hline Items & Frequency & Percentage \\
\hline \multicolumn{3}{|l|}{ Menstruation } \\
\hline White discharge & 21 & 19.8 \\
\hline Uterine bleeding & 55 & 51.9 \\
\hline Bleeding from stomach & 30 & 28.3 \\
\hline \multicolumn{3}{|c|}{ Belief regarding causes of menstruation } \\
\hline Hormonal & 25 & 23.6 \\
\hline Natural & 61 & 57.5 \\
\hline Physical & 20 & 18.9 \\
\hline \multicolumn{3}{|l|}{ Menarche Age } \\
\hline $11-13$ years & 72 & 67.9 \\
\hline $14-16$ years & 34 & 32.1 \\
\hline \multicolumn{3}{|c|}{ Feeling about first menstruation (multiple response) } \\
\hline Surprised & 71 & 67.0 \\
\hline Afraid & 47 & 44.3 \\
\hline Got nervous & 39 & 36.8 \\
\hline Normal & 58 & 54.7 \\
\hline \multicolumn{3}{|c|}{ Concept about menstrual hygiene } \\
\hline Taking rest & 16 & 15.1 \\
\hline $\begin{array}{l}\text { Taking supplementary } \\
\text { food }\end{array}$ & 20 & 18.9 \\
\hline Use sanitary pad & 70 & 66.0 \\
\hline \multicolumn{3}{|c|}{$\begin{array}{l}\text { Sources of information about menstruation before } \\
\text { menarche (multiple response) }\end{array}$} \\
\hline Mother & 72 & 67.9 \\
\hline Sister & 101 & 95.3 \\
\hline Friend & 98 & 92.5 \\
\hline Teacher & 66 & 62.3 \\
\hline \multicolumn{3}{|l|}{ Usual menstrual cycle } \\
\hline Regular & 84 & 79.2 \\
\hline Irregular & 22 & 20.8 \\
\hline \multicolumn{3}{|c|}{ Experience of inter menstrual interval } \\
\hline$<25$ days & 22 & 20.8 \\
\hline 25-28 days & 53 & 50.0 \\
\hline 28-35 days & 19 & 17.9 \\
\hline$>35$ days & 12 & 11.3 \\
\hline \multicolumn{3}{|c|}{ Duration of menstrual cycle during each period } \\
\hline$<2$ days & 14 & 13.2 \\
\hline 2-3 days & 28 & 26.4 \\
\hline 3-5 days & 43 & 40.6 \\
\hline$>5$ days & 21 & 19.8 \\
\hline
\end{tabular}

\section{Practice about menstrual hygiene}

Table 3 showed that about $64.2 \%$ of the respondent's mentioned that the material used during menstruation was sanitary pad, followed by new cloth $(29.2 \%)$ and the rest used old washed cloth $(6.6 \%)$. More than half $(55.7 \%)$ of them stated that they changed the material once a day and $27.4 \%$ of them mentioned they changed the material twice a day. About $55.7 \%$ of the respondents mentioned that adequate absorption was their perception regarding sanitary pad and $46.2 \%$ of them mentioned that comfortability was their perception regarding use of sanitary cloth.

Table 3: Practice about menstrual hygiene $(n=106)$.

\begin{tabular}{|c|c|c|}
\hline Items & Frequency & Percentage \\
\hline \multicolumn{3}{|c|}{ Material use during menstruation } \\
\hline Sanitary pad & 68 & 64.2 \\
\hline Old cloth & 7 & 6.6 \\
\hline New cloth & 31 & 29.2 \\
\hline \multicolumn{3}{|c|}{ Frequency of changing material used } \\
\hline Once a day & 59 & 55.7 \\
\hline Twice a day & 29 & 27.4 \\
\hline More than three times & 18 & 16.9 \\
\hline \multicolumn{3}{|c|}{ Perception regarding sanitary pad } \\
\hline Comfortable & 26 & 24.5 \\
\hline Adequate absorption & 59 & 55.7 \\
\hline Do not stain clothes & 21 & 19.8 \\
\hline \multicolumn{3}{|c|}{ Perception regarding sanitary cloth } \\
\hline Comfortable & 49 & 46.2 \\
\hline Adequate absorption & 35 & 33.0 \\
\hline Do not stain clothes & 22 & 20.8 \\
\hline \multicolumn{3}{|c|}{ Reason for not using sanitary pad } \\
\hline Cost & 33 & 31.1 \\
\hline Difficulty in disposal & 36 & 34.0 \\
\hline Lack of knowledge & 11 & 10.4 \\
\hline Other reason & 15 & 24.5 \\
\hline \multicolumn{3}{|c|}{ Mode of disposal of absorbents } \\
\hline Burn & 17 & 16.0 \\
\hline Burry & 8 & 7.5 \\
\hline Dustbin & 81 & 76.5 \\
\hline \multicolumn{3}{|c|}{ Material used for Genital Cleaning } \\
\hline Water only & 11 & 10.4 \\
\hline Water and soap & 73 & 68.9 \\
\hline Water and anti-septic & 22 & 20.7 \\
\hline \multicolumn{3}{|c|}{ Excess bleeding during menstruation } \\
\hline Yes & 29 & 27.4 \\
\hline No & 77 & 72.6 \\
\hline \multicolumn{3}{|c|}{ Excess pain during menstruation } \\
\hline Yes & 38 & 35.8 \\
\hline No & 68 & 64.2 \\
\hline \multicolumn{3}{|c|}{$\begin{array}{l}\text { Feel weak and unable to take food during } \\
\text { menstruation }\end{array}$} \\
\hline Yes & 31 & 29.2 \\
\hline No & 75 & 70.8 \\
\hline
\end{tabular}

Most of the respondents $(34.4 \%)$ mentioned that difficulty in disposal was their reason for not using sanitary pad, followed by cost as mentioned by $31.1 \%$, other reason as mentioned by $24.5 \%$ and the rest 
mentioned lack of knowledge (10.4\%). About $76.5 \%$ of the respondents mentioned that their mode of disposal of absorbents was dustbin and most of them $(68.9 \% 0$ used water and soap to clean their genital area after menstruation. Less than three-tenths $(27.4 \%)$ of the respondents had excess bleeding during menstruation and only $35.8 \%$ of them had excess pain during menstruation. About $29.2 \%$ of the study participants mentioned they feel weak and unable to take food during menstruation.

\section{Level of knowledge and practice on menstrual hygiene}

Table 4 showed that about $57.5 \%$ of the respondents had moderate level of knowledge regarding the menstrual hygiene, $22.6 \%$ of them had good level of knowledge and $19.9 \%$ of them had poor level of knowledge on menstrual hygiene. On the other hand about $53.4 \%$ of the study participants had moderate level of practice on menstrual hygiene, $28.7 \%$ of them had good level of practice and the rest had poor level of practice regarding the menstrual hygiene $(17.9 \%)$.

Table 4: Level of knowledge and practice on menstrual hygiene.

\begin{tabular}{|lll|}
\hline Score & $\begin{array}{l}\text { Level of knowledge } \\
\text { on menstrual } \\
\text { hygiene }\end{array}$ & $\begin{array}{l}\text { Level of practice } \\
\text { on menstrual } \\
\text { hygiene }\end{array}$ \\
\hline Good & $24(22.6)$ & $41(38.7)$ \\
\hline Moderate & $61(57.5)$ & $46(43.4)$ \\
\hline Poor & $21(19.9)$ & $19(17.9)$ \\
\hline Total & $\mathbf{1 0 6}(\mathbf{1 0 0 . 0})$ & $\mathbf{1 0 6}(\mathbf{1 0 0 . 0})$ \\
\hline
\end{tabular}

\section{DISCUSSION}

In this study little above half (51.9\%) of the respondents mentioned that menstruation is the uterine bleeding. $28.3 \%$ of them mentioned that is the bleeding from stomach and $19.8 \%$ stated that menstruation is the white discharge. Regarding the causes of menstruation about $57.5 \%$ of the respondents mentioned that it occurs naturally, $23.6 \%$ mentioned that it is hormonal and $18.9 \%$ of them mentioned that it's physical. A study reported that 1 out of every 3 girls in South Asia knew nothing about menstruation before attaining menarche and another study from India reported that $10 \%$ of the girls believed that menstruation is a disease. ${ }^{5}$

The majority $(67.0 \%)$ of the respondents were surprised during their first menstruation, $54.7 \%$ of them mentioned that its normal for them and $44.3 \%$ were afraid during first menstruation. A study presented that menstruation is a normal process; but in most parts of the world, it remains a taboo and is rarely talked about. ${ }^{6}$

Most of the respondents source of information about menstruation before menarche was sister (95.3\%), followed by friend $(92.5 \%)$, mother $(67.9 \%)$ and the rest mentioned the teacher $(62.3 \%)$. This findings is consistent to that of similar study conducted in neighboring country India. ${ }^{7}$

About $64.2 \%$ of the respondent's mentioned that the material used during menstruation was sanitary pad, followed by new cloth $(29.2 \%)$ and the rest used old washed cloth $(6.6 \%)$. A similar study reported the following practices during menstruation $-11.25 \%$ of the girls used sanitary pads during menstruation, $42.5 \%$ of them used old cloth pieces and $6.25 \%$ of the girls used new cloth pieces. ${ }^{8}$

About $57.5 \%$ of the respondents had moderate level of knowledge regarding the menstrual hygiene, $22.6 \%$ of them had good level of knowledge and $19.9 \%$ of them had poor level of knowledge on menstrual hygiene. This is similar to the findings of another study conducted in northern part of Nigeria. ${ }^{9}$

On the other hand about $53.4 \%$ of the study participants had moderate level of practice on menstrual hygiene, $28.7 \%$ of them had good level of practice and the rest had poor level of practice regarding the menstrual hygiene $(17.9 \%)$. This finding is lower than that of similar study conducted in Ethiopia were they found $90.9 \%$ had good practice regarding the menstrual hygiene. ${ }^{10}$

\section{CONCLUSION}

The study was concluded that more than half of the respondents had moderate level of knowledge and practice regarding the menstrual hygiene. Most of the $(67.0 \%)$ of the respondents were surprised during their first menstruation and close to eight-tenths (79.2\%) mentioned they had a regular usual menstrual cycle. About $64.2 \%$ of the respondents stated that the material used during menstruation was sanitary pad and more than half $(55.7 \%)$ of them changed the material once a day. There is need for more awareness regarding the information on good menstrual hygiene practices. Schools and colleges should add more effort in provision or creating awareness about the important of good menstrual hygiene among the students and the community as a whole.

Funding: No funding sources

Conflict of interest: None declared

Ethical approval: The study was approved by the Institutional Ethics Committee

\section{REFERENCES}

1. Reid G, Bruce AW. Urogenital infections in women: can probiotics help? Postgrad Med J. 2003:79:42832.

2. Water Aid. Menstrual hygiene and management an issue for adolescent school girls. 2009. Available at: www.wateraid.org/nepal.

3. Narayan KA, Srinivasa DK, Pelto PJ, Veerammal S. Puberty rituals, reproductive knowledge and health 
of adolescent schoolgirls in South India. Asia-Pac Popul J. 2001:16(2):225-38.

4. Ibrahim A, Bukar AG, Godpower CM. Menstrual hygiene practices among female adolescents seen in general outpatient. Clinic Tropical J Obstet Gynaecol. 2018;35(3):281-5.

5. WASH United - Menstrual hygiene management: 2016. Available at: http://www.wash-united.org/ourwork/issues/menstrual-hygiene-management.

6. House S, Mohan T, Cavill S. Menstrual hygiene matters. A resource for improving menstrual hygiene around the world. Water Aid. 2012:354.

7. Bhattacherjee S, Ray K, Biswas R, Chakraborty M. Menstruation experiences of adolescent slum dwelling girls of siliguri city, West Bengal. India J Basic Clinic Reprod Sci. 2013:2:(2):85-91.

8. Dasgupta A, Sarkar M. Menstrual hygiene: how hygienic is the adolescent girl? Indian J Com Med. 2008;33(2):77-80.
9. Lawan U, Nafisa W, Musa A. Menstruation and menstrual hygiene amongst adolescent school girls in Kano Northwestern Nigeria. Afr J Reprod Health. 2010;14(3):201-7.

10. Teklemariam G. Practice of menstrual hygiene and associated factors among female Mehalmeda high school students in Amhara Regional State, Ethiopia. Sci J Public Health. 2014;2(3):189-95.

Cite this article as: Nahar NS, Khatun R, Halim KMA, Islam S, Muhammad F. Assessment of knowledge and practice of menstrual hygiene among the female nursing students in a selected private nursing college in Dhaka City. Int J Reprod Contracept Obstet Gynecol 2019;8:1847-51. 